\title{
Crop rotation biomass and arbuscular mycorrhizal fungi effects on sugarcane yield
}

\author{
Edmilson José Ambrosano1*; Rozario Azcón²; Heitor Cantarella; Gláucia Maria Bovi \\ Ambrosano5; Eliana Aparecida Schammass; ${ }^{6}$ Takashi Muraoka ; Paulo César Ocheuze \\ Trivelin ${ }^{7}$; Fabrício Rossi ${ }^{1}$; Nivaldo Guirado ${ }^{1}$; Maria Regina Gonçalves Ungaro ${ }^{4}$; Juliana \\ Rolim Salomé Teramoto ${ }^{1}$ \\ ${ }^{1}$ Apta - Pólo Regional Centro Sul, C.P. 28 - 13400-970 - Piracicaba, SP - Brasil. \\ ${ }_{3}^{2}$ Estação Experimental de Zaidin CSIC, Profesor Albareda, 1, 18008, Granada - Espanha. \\ ${ }_{4}^{3}$ AptalIAC - Centro de Solos e Recursos Ambientais, C.P. 28 - 13001-970 - Campinas, SP - Brasil. \\ Apta/IAC - Centro de Plantas Graníferas. In memorian \\ UNICAMP/FOP - Depto. de Odontologia Social, Bioestatistica, C.P. 52 - 13414-903 - Piracicaba, SP - Brasil. \\ ${ }_{7}^{6}$ Apta/IZ, Bioestatística, R. Heitor Penteado, 56 - 13460-000 - Nova Odessa, SP - Brasil. \\ ${ }^{7}$ USP/CENA, C.P. 96 - 13400-970 - Piracicaba, SP - Brasil. \\ *Corresponding author < ambrosano@apta.sp.gov.br>
}

ABSTRACT: Sugarcane (Saccharum spp.) is an important crop for sugar production and agro-energy purposes in Brazil. In the sugarcane production system after a 4- to 8-year cycle crop rotation may be used before replanting sugarcane to improve soil conditions and give an extra income. This study had the objective of characterizing the biomass and the natural colonization of arbuscular mycorrhizal fungi (AMF) of leguminous green manure and sunflower (Helianthus annuus L.) in rotation with sugarcane. Their effect on stalk and sugar yield of sugarcane cv. IAC 87-3396 grown subsequently was also studied. Cane yield was harvested in three subsequent cuttings. Peanut cv. IAC-Caiapó, sunflower cv. IAC-Uruguai and velvet bean (Mucuna aterrimum Piper and Tracy) were the rotational crops that resulted in the greater percentage of AMF. Sunflower was the specie that most extracted nutrients from the soil, followed by peanut cv. IAC-Tatu and mung bean (Vigna radiata $\mathrm{L}$. Wilczek). The colonization with $\mathrm{AMF}$ had a positive correlation with sugarcane plant height, at the first cut $(p=0.01$ and $R=0.52)$ but not with the stalk or cane yields. Sunflower was the rotational crop that brought about the greatest yield increase of the subsequent sugarcane crop: $46 \%$ increase in stalk yield and 50\% in sugar yield compared with the control. Except for both peanut varieties, all rotational crops caused an increase in net income of the cropping system in the average of three sugarcane harvests.

Key words: green manure, legumes, biological nitrogen fixation, sugarcane stalk yield

\section{Produção de biomassa e presença de fungos micorrízicos arbusculares em culturas utilizadas em rotação com a cana-de-açúcar}

\begin{abstract}
RESUMO: A cana-de-açúcar (Saccharum spp.) vem sendo cultivada no Brasil para produção de açúcar e agroenergia. Em seu sistema de produção, após um ciclo de 4 a 8 anos, é possível a rotação com plantas de cobertura, antes do seu replantio, para melhoria do solo e geração de renda. Estudou-se a caracterização e produtividade de biomassa de leguminosas (como adubos-verdes) e girassol (Helianthus annuus L.), a ocorrência natural de micorrizas, o teor de açúcar e a produtividade em colmos da cana-de-açúcar IAC 87-3396 e a viabilidade econômica desse sistema com cultivo após as opções de rotação, com quantificação da produtividade durante três cortes consecutivos. $\mathrm{O}$ amendoim (Arachis hypogaea L.) cv. IAC-Caiapó, girassol cv. IAC-Uruguai e mucuna-preta (Mucuna aterrimum Piper and Tracy) foram as culturas que apresentaram maior percentagem de colonização por fungos micorrízicos. $\mathrm{O}$ girassol foi a planta de cobertura que mais extraiu nutrientes do solo, seguido por amendoim (Arachis hipogaea L.) cv. IAC-Tatu e feijão-mungo (Vigna radiata L. Wilczek). A colonização por fungos micorrízicos mostrou correlação positiva com a altura de plantas de cana no primeiro corte $(p=0,01$ e $R=0,52)$, mas não se correlacionou com a produtividade de colmos ou açúcar. No primeiro corte, o girassol foi a cultura de rotação que ocasionou o maior aumento de produtividade, da ordem de $46 \%$ em colmos e de 50\% na quantidade de açúcar, em comparação com a testemunha. Com exceção dos amendoins, todas as culturas em rotação aumentaram a renda líquida do sistema na média de três cortes de cana-de-açúcar.

Palavras-chave: adubo verde, leguminosas, fixação biológica de nitrogênio, produção de colmos de cana-de-açúcar
\end{abstract}

\section{Introduction}

The cycle of a sugarcane crop, including plant cane and ratoons, is of five to eight years, depending on the soil characteristics and cultivar. As yields decline with time sugarcane must be replanted. Between sugarcane cycles, there is a time span of about three to five months, usually in the spring and summer in Central and South- 
eastern Brazil, in which a rotational crop can be grown. Otherwise the soil would be idle during this rainy period (about $950 \mathrm{~mm}$ in six months), subject to weed growth and soil erosion (Caceres and Alcarde, 1995).

There are many benefits to the sugarcane crop of leguminous plants grown in rotation in sugarcane renovation areas; these include the recycling of nutrients taken up from deep soil layers by the rotational crop, which may prevent or decrease leaching losses, and the addition of $\mathrm{N}$ from biological fixation (Miyasaka, 1984; Miyasaka and Okamoto, 1993). Leguminous plants can accumulate over $5 \mathrm{t} \mathrm{ha}^{-1}$ of dry mass during a short period of time during the summer and take up large amounts of $\mathrm{N}$ and $\mathrm{K}$. Most of this $\mathrm{N}$ comes from the association of legumes with rhizobia. In this way crop rotation with legumes can replace partially or totally $\mathrm{N}$ mineral fertilization of sugarcane, at least for the first ratoon (Albuquerque et al., 1980; Ambrosano et al., 2005).

Another important microbial association is that of mycorrhizal fungi and plant roots. These fungi are present in over $80 \%$ of plant species (Azcón et al., 1991). In contrast with the large diversity of plants, which includes sugarcane, that have their roots colonized by mycorrhizas, only 150 fungi species are responsible for that colonization (Azcón et al., 1991). A crop whose roots are colonized by mycorrhizal fungi can raise the soil mycorrhizal potential which can benefit plants which are responsive to this fungi association and that are cultivated in sequence. This could be particularly useful for the nutritional management of crops in low nutrient, low input-output systems of production (Panja and Chaudhuri, 2004).

The purposes of this paper were: i) to evaluate the effect of crop rotation with several legume species and with sunflower on the yield and nitrogen status of the sugarcane plant; ii) to evaluate the natural root colonization of sunflower and the leguminous green manure plants with arbuscular-mycorrhizal fungi (AMF); and iii) to study the impact of crop rotation on soil chemical conditions as well as to analyze the economical viability of crop rotation in a sugarcane production system.

\section{Material and Methods}

The experiment was carried out from December 2000 to December 2004 in Piracicaba, state of São Paulo, Bra- zil (22 $42^{\prime} \mathrm{S}, 47^{\circ} 38^{\prime} \mathrm{W}$ and $560 \mathrm{~m}$ altitude). The soil is as a Typic Paleudult and was chemically characterized at different depths with samples taken after the green manures were cut but before sugarcane was planted (Table 1). The experimental design was a randomized block with eight treatments and five replications. The treatments consisted of seven rotational crops plus a control (fallow) grown before sugarcane was planted. The rotational crops were peanut (Arachis hypogaea L.) cv. Tatu, peanut cv. IAC-Caiapo, sunn hemp cv. IAC 2(Crotalaria juncea L.), velvet bean (Mucuna aterrimum Piper and Tracy), soybean (Glycine max L. Merrill) cv. IAC-17, sunflower (Helianthus annuus L.) cv. IAC-Uruguai, and mung bean (Vigna radiata L. Wilczek).

The green manures were sowed in December 2000 on $7 \mathrm{~m} \times 10 \mathrm{~m}$ size plots, with rows $0.50 \mathrm{~m}$ apart. The experimental area was weeded $30 \mathrm{~d}$ after sowing, and the weed residues were left on the soil surface. The rotational crops were neither limed nor fertilized. A summary of the experimental procedures and respective dates are presented in Table 2.

During seed filling, the plants used as green manure were manually cut and spread on the soil covering the entire plot surface in pieces less than $0.25 \mathrm{~m}$ and left there for six months. Peanut, soybean, sunflower and mung bean were harvested after physiological maturation for the grain yield, and the remaining plant parts were cut and spread on the soil. Biomass production of the rotational crops was evaluated in $1 \mathrm{~m}^{2}$ of the plot area. Plant shoot was oven-dried $\left(60^{\circ} \mathrm{C}\right)$ for the determination of dry mass and $\mathrm{N}$ and $\mathrm{C}$ concentrations were measured by mass spectrometry using the sampling preparation procedures described by Trivelin et al. (1973). The biological nitrogen fixation (BNF) by leguminous plants was determined by natural abundance of ${ }^{15} \mathrm{~N}$ technique $\left(\delta^{15} \mathrm{~N}\right)$ (Shearer and Kohl, 1986), and sunflower was the non-N fixing specie. The chemical analysis of plants to determine macro and micronutrient contents were performed according to the methods proposed by Bataglia et al. (1983).

At the harvest stage, the roots of each rotational crop were sampled in order to evaluate the natural colonization level of arbuscular mycorrhizal fungi (AMF). The colonization percentage was estimated using the root coloration technique according to Philips and Hayman (1970): the roots were treated with a $10 \%(\mathrm{~m} / \mathrm{v}) \mathrm{KOH}$

Table 1 - Soil chemical characteristics in samples collected after the rotational crop and before the sugarcane was planted.

\begin{tabular}{|c|c|c|c|c|c|c|c|c|c|c|}
\hline & & $\mathrm{OM}$ & $\begin{array}{c}\mathrm{pH} \\
\mathrm{CaCl}_{2}\end{array}$ & $\mathrm{P}$ & K & $\mathrm{Ca}$ & $\mathrm{Mg}$ & $\mathrm{H}+\mathrm{Al}$ & CEC & V \\
\hline & & $\mathrm{g} \mathrm{dm}^{-3}$ & & $\mathrm{mg} \mathrm{dm^{-3 }}$ & 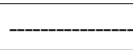 & $-n$ & $1_{c} d_{m}^{-}$ & $\ldots$ & ב... & $\%$ \\
\hline \multirow[t]{2}{*}{ Control } & $1^{1}$ & 20 & 5.5 & 13 & 0.6 & 33 & 21 & 23 & 79 & 68 \\
\hline & 2 & 19 & 5.5 & 10 & 0.4 & 29 & 19 & 25 & 74 & 64 \\
\hline Rotational & 1 & 23 & 5.9 & 16 & 0.5 & 37 & 29 & 23 & 80 & 73 \\
\hline crops & 2 & 21 & 5.7 & 20 & 0.6 & 32 & 23 & 26 & 83 & 67 \\
\hline
\end{tabular}

${ }^{1}$ Sampling layer $1=0-0.2 \mathrm{~m} ; 2=0.2-0.4 \mathrm{~m}$. 
solution, maintained below $90^{\circ} \mathrm{C}$ during $50 \mathrm{~min}$. Afterwards the roots were washed with running water, clarified with a $1 \%(\mathrm{v} / \mathrm{v}) \mathrm{HCl}$ solution, and stained with trypan blue. The percentage of colonization by AMF was estimated by counting the roots' stained portions using a reticular plate under a microscope following the procedures described by Giovanetti and Mosse (1980).

After harvesting the rotational crops the soil was sampled at the 0-0.2 $\mathrm{m}$ and 0.2-0.4 $\mathrm{m}$ depths for fertility analysis according to the methods described in Raij et al. (2001).

Stalks of sugarcane cv. IAC-87-3396 were planted in April but the crop had to be replanted in September due to the lack of rainfall. The sugarcane plots, with five 10$\mathrm{m}$-long rows $1.40 \mathrm{~m}$ apart, were set up on top of the rotational crops' plots (Table 2). Sugarcane was fertilizer with $500 \mathrm{~kg} \mathrm{ha}^{-1}$ of a 08-28-16 $\left(\mathrm{N}, \mathrm{P}_{2} \mathrm{O}_{5}, \mathrm{~K}_{2} \mathrm{O}\right)$ formulation at planting and with a $20-05-20\left(\mathrm{~N}, \mathrm{P}_{2} \mathrm{O}_{5}, \mathrm{~K}_{2} \mathrm{O}\right)$ formulation after the first and the second cutting to assure adequate crop development (Table 2). Weeds were controlled with the post-emergence herbicide metribuzin $\left(1.92 \mathrm{~L} \mathrm{ha}^{-1}\right)$ applied to the sugarcane field after each harvest. No irrigation was used in the area. Total monthly rainfall and local temperature were measured at the meteorological station near the experimental site (Figure 1).

To evaluate sugarcane stalk yield 2-m sections of each of the three central rows were cut and weighed. Ten successive stems were separated from each plot for the technological evaluation of the Brix, pol, and total recovered sugar (Tanimoto, 1964). Sugar yield, expressed in terms of tons of pol per hectare (TPH), was estimated with the stem yield and technological analysis data.

The economic balance considered the costs of production and revenues of the rotational crops as well as three harvests of sugarcane. The basic costs of production of sugarcane (including land preparation, seed stalk, fertilizer, herbicides feedstock and application, and harvesting) were the average of the 2004, 2005, and 2006 prices, based on an average stalk yield of $70 \mathrm{t} \mathrm{ha}^{-1}$. For the control treatment, which did not include the crop rotations, the cost of production of sugarcane was estimated as U\$ 3,111 ha ${ }^{-1}$. The costs of production of the green manures crotalaria and velvet beans, U\$ $100 \mathrm{ha}^{-1}$, include seeds, planting, and cutting. For the grain crops, the costs of grain harvesting and of chemicals needed for phytosanitary control were added: sunflower (U\$ 422 $\left.\mathrm{ha}^{-1}\right)$, peanut cv. Tatu (U\$ 1,289 $\left.\mathrm{ha}^{-1}\right)$, Peanut cv. IACCaiapó (U\$ 1,480 ha ${ }^{-1}$ ), mung bean (U\$ 2,007 ha ${ }^{-1}$ ) and soybean $\left(\mathrm{U} \$ 513 \mathrm{ha}^{-1}\right)$. The sales prices of grain and cane stalks for the period between 2004 and 2006 (according to a database of the Institute of Agricultural Economics of the São Paulo State Secretary of Agriculture) were: sugarcane stalks, U\$ $17.56 \mathrm{t}^{-1}$; sunflower, U\$ $178 \mathrm{t}^{-1}$; peanut cv. Tatu, U\$ $260 \mathrm{t}^{-1}$; peanut cv. IAC-Caiapó, U\$ 260 $\mathrm{t}^{-1}$; soybean, U\$ $197 \mathrm{t}^{-1}$; and mung bean, U\$2,222 $\mathrm{t}^{-1}$. Mung bean is not sold as a commodity but as a specialty crop; its prices are highly variable, and the market for it is relatively small; therefore, the data on the economical return for mung bean must be taken with care.

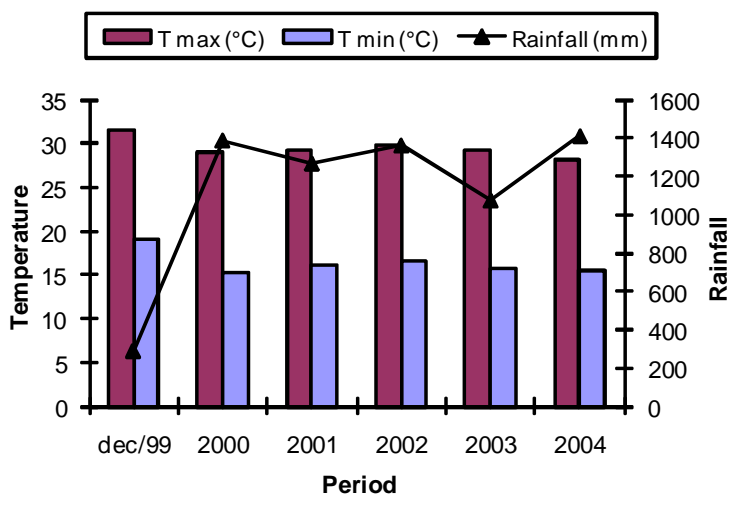

Figure 1 - Climatological data of maximum and minimum annual average temperature, and annual average rainfall from December 1999 to December 2004.

Table 2 - Chronology of the events on the experimental field.

\begin{tabular}{|c|c|}
\hline Date & Activity \\
\hline December 27,2000 & Green manures, grain legumes, and sunflower sowed \\
\hline January 27, 2001 & Weeds cut and left on soil surface \\
\hline March 28, 2001 & $\begin{array}{l}\text { Grains harvested (grain crops) and green manures cut and left on soil surface. Roots sampled for } \\
\text { evaluating natural asbuscular mycorrhizal fungi colonization }\end{array}$ \\
\hline April 4, 2001 & Soil sampling: $0-0.2 \mathrm{~m}$ and $0.2-0.4 \mathrm{~m}$ layers \\
\hline April 16, 2001 & Crop residues mechanically chopped. Sugarcane planted \\
\hline September 12, 2001 & Sugarcane replanted because the first planting did not succeed due to drought \\
\hline December 12, 2001 & Post emergence herbicide metribuzin applied to control weeds. \\
\hline September 25, 2002 & Sugarcane harvested (first cut) \\
\hline December 18, 2002 & Fertilizer and herbicide applied to sugarcane ratoon crop \\
\hline July 30,2003 & Sugarcane harvested (second cut) \\
\hline November 18, 2002 & Fertilizer and herbicide applied to second ratoon crop \\
\hline December 28, 2004 & Sugarcane harvested (third cut) \\
\hline
\end{tabular}


A randomized block design with five replicates in a split-plot scheme was used for the soil organic matter and $\mathrm{Mg}$ content analysis. The plots were the crop rotation and the subplots the depth. For the comparison between the rotation means, the Scott-Knott and the F test were utilized for depth, with $\alpha=0.05$.

The experimental block design was used for evaluating the sugarcane stalk and sugar yield and the steam height, with five replications, eight treatments and three cuttings. In the statistical design the treatment, season, and their interaction effects were considered as fixed, whereas blocks were random effects. The statistical analysis was performed using the concept of measurements repeated in time and the MIXED procedure in the SAS (Statistical Analysis System) version 8.2 for Windows software (Littel et al., 1996). The Akaike information criterion was used to select the variance and covariance matrix, by choosing the matrix with the smallest value for that parameter (Akaike, 1974 and SAS Institute, 2004). The adjusted means for the fixed effects were obtained with the "LSMEANS" option, and mean comparisons were made by the Tukey - Kramer test $(\alpha=0.1)$.

Grain and biomass yield, economic viability and nutrient extraction data were analyzed as randomized block design using analysis of variance and F-test procedures, after data transformation to $\log (x)$ since the assumptions of the mathematical model were violated. Comparisons among means were made according to Scott-Knott test $(\alpha=0.05)$.

\section{Results and Discussion}

Sunflower accumulated more above-ground dry matter of total biomass and soybean more grain yield than the other crops (Table 3). Soybean, sunn hemp, velvet bean, and sunflower extracted the greatest amounts of $\mathrm{N}$ and $\mathrm{P}$ (Table 4). Sunflower also recycled more of K, $\mathrm{Ca}, \mathrm{Mg}$, and $\mathrm{Zn}$ than the other rotational crops, probably as a consequence of the higher biomass yield (Tables 3 and 4).

Soybean presented the highest $\mathrm{N}$ content, and sunflower the lowest. No differences were observed between peanuts and velvet bean and between sunn hemp and mung bean (Table 5). Among the macronutrients, $\mathrm{N}$ had the highest and $\mathrm{P}$ the lowest accumulation in the rotational crops. On the average $\mathrm{Fe}$ was recycled in the highest amounts in the above-ground parts of the rotational crops and $\mathrm{Zn}$ in the lowest (Table 4). The same

Table 3 - Dry mass and grain yields of the rotational crops.

\begin{tabular}{lcc}
\hline Rotational crop & Above-ground dry matter & Grain yield ${ }^{1}$ \\
\hline Control & - & - \\
Mung bean cv. M146 & $2,225 \mathrm{~d}$ & $798 \mathrm{~d}$ \\
Peanut cv. IAC-Caiapó & $1,905 \mathrm{~d}$ & $1,096 \mathrm{c}$ \\
Peanut cv. Tatu & $1,783 \mathrm{~d}$ & $1,349 \mathrm{c}$ \\
Soybean cv. IAC-17 & $3,669 \mathrm{c}$ & $2,970 \mathrm{a}$ \\
Sunflower cv. IAC-Uruguai & $15,229 \mathrm{a}$ & $1,805 \mathrm{~b}$ \\
Sunn hemp cv. IAC 2 & $6,230 \mathrm{~b}$ & - \\
Velvet bean & $5,049 \mathrm{~b}$ & - \\
\hline C.V. $(\%)$ & 5.1 & 22.1 \\
\hline
\end{tabular}

Means followed by the same letter in the columns are not different (Scott-Knott, $p=0.05)$. ${ }^{1}$ Data were log-transformed $(x)$.

Table 4 - Nutrient content of above ground biomass of the rotational crops, excluding the grains.

\begin{tabular}{|c|c|c|c|c|c|c|c|c|}
\hline Rotational crops & $\mathrm{N}$ & $\mathrm{P}$ & $\mathrm{K}^{1}$ & $\mathrm{Ca}^{1}$ & $\mathrm{Mg}^{1}$ & $\mathrm{Fe}^{1}$ & $\mathrm{Mn}^{1}$ & $\mathrm{Zn}^{1}$ \\
\hline & \multicolumn{5}{|c|}{$\mathrm{kg} \mathrm{ha}^{-1}$} & \multicolumn{3}{|c|}{$\mathrm{g} \mathrm{ha}^{-1}$} \\
\hline Control & - & - & - & - & - & - & - & - \\
\hline Mung bean cv. M146 & $27 \mathrm{~b}$ & $2.4 \mathrm{~b}$ & $17 \mathrm{~d}$ & $17 \mathrm{~d}$ & $12 \mathrm{~d}$ & $2,073 \mathrm{a}$ & $258 \mathrm{a}$ & $43 c$ \\
\hline Peanut cv. IAC-Caiapo & $39 \mathrm{~b}$ & $2.7 \mathrm{~b}$ & $35 \mathrm{c}$ & $19 \mathrm{~d}$ & $13 \mathrm{c}$ & 3,279 a & $222 \mathrm{a}$ & $47 \mathrm{c}$ \\
\hline Peanut cv. Tatu & $34 \mathrm{~b}$ & $3.8 \mathrm{~b}$ & $27 \mathrm{c}$ & $18 \mathrm{~d}$ & $11 \mathrm{c}$ & 1,679 a & $81 \mathrm{~b}$ & $37 \mathrm{c}$ \\
\hline Soybean cv. IAC-17 & $122 \mathrm{a}$ & $8.7 \mathrm{a}$ & $14 \mathrm{~d}$ & $46 c$ & $28 \mathrm{~b}$ & $1,424 \mathrm{a}$ & 186 a & $55 \mathrm{c}$ \\
\hline Sunflower cv. IAC-Uruguai & $71 \mathrm{a}$ & $7.7 \mathrm{a}$ & $120 \mathrm{a}$ & $171 \mathrm{a}$ & $98 \mathrm{a}$ & 2,736 a & $324 a$ & $259 \mathrm{a}$ \\
\hline Sunn hemp cv. IAC 2 & 97 a & $5.8 \mathrm{a}$ & $33 \mathrm{c}$ & $34 \mathrm{c}$ & $21 \mathrm{~b}$ & $1,313 \mathrm{~b}$ & 178 a & $84 \mathrm{~b}$ \\
\hline Velvet bean & 109 a & $8.9 \mathrm{a}$ & $50 \mathrm{~b}$ & $61 \mathrm{~b}$ & $17 \mathrm{~b}$ & 792 a & $159 \mathrm{a}$ & $90 \mathrm{~b}$ \\
\hline C.V. (\%) & 10.9 & 42.5 & 13.3 & 9.7 & 13.0 & 9.5 & 10.1 & 9.9 \\
\hline
\end{tabular}

Means followed by the same letter the columns are not different (Scott-Knott, $p=0.05)$. ${ }^{1}$ Data were log-transformed $(\times)$. 
Table 5 - Carbon and nitrogen concentration, carbon to nitrogen ratio, and $\mathrm{N}$ derived from biological $\mathrm{N}_{2}$ fixation (BNF) in the aboveground parts of the rotational crops at harvesting.

\begin{tabular}{lcccc}
\hline Rotational crop & C content & N content & C : N & N-BNF \\
\hline & $426 \mathrm{a}$ & $12.5 \mathrm{c}$ & $34.1 \mathrm{~b}$ & $\%$ \\
\hline Mung bean cv. M146 & $424 \mathrm{a}$ & $20.9 \mathrm{~b}$ & $20.3 \mathrm{~b}$ & $70 \mathrm{~b}$ \\
Peanut cv. IAC-Caiapó & $440 \mathrm{a}$ & $19.2 \mathrm{~b}$ & $23.0 \mathrm{~b}$ & $38 \mathrm{c}$ \\
Peanut cv. Tatu & $426 \mathrm{a}$ & $31.9 \mathrm{a}$ & $13.3 \mathrm{~b}$ & $27 \mathrm{c}$ \\
Soybean cv. IAC-17 & $429 \mathrm{a}$ & $4.6 \mathrm{~d}$ & $92.4 \mathrm{a}$ & - \\
Sunflower cv. IAC-Uruguai & $449 \mathrm{a}$ & $17.2 \mathrm{c}$ & $26.1 \mathrm{~b}$ & $69 \mathrm{~b}$ \\
Sunn hemp cv. IAC 2 & $446 \mathrm{a}$ & $21.6 \mathrm{~b}$ & $20.7 \mathrm{~b}$ & $62 \mathrm{~b}$ \\
Velvet bean & 2.8 & 19.1 & 19.6 & 13.7 \\
\hline${ }^{1}$ C.V. $(\%)$ & &
\end{tabular}

Means followed by the same letter in the columns are not different (Scott-Knott, $p=0.05) .{ }^{1}$ Coefficient of variation.

results were observed by Silveira et al. (2005) who evaluated pigeon pea (Cajanus cajan) and stylo plants (Stylosanthes guianensis var. vulgaris cv. Mineirão).

The high AMF infection rate, which helps the uptake of micronutrients (Table 6), may explain the high amounts of $\mathrm{Zn}$ returned to the soil when sunflower was grown before sugarcane. There is an increasing utilization of sunflower as a crop rotation with sugarcane in Brazil, due to its use for silage, seed oil production, and to its potential as a feedstock for biodiesel (Porto et al., 2008)

The amounts of $\mathrm{N}$ in the above-ground parts of sunn hemp (Table 4) were relatively low compared to those of Caceres and Alcarde (1995), who reported the extraction of up to $230 \mathrm{~kg} \mathrm{ha}^{-1}$ of N, and to those of Ambrosano et al. (2005), who found $196 \mathrm{~kg} \mathrm{ha}^{-1}$ of N. However, the amounts of $\mathrm{N}$ returned to the soil are directly related to the nutrient concentration in the plant, which varies with the local potential for biological nitrogen fixation (BNF) and with the growth stage of the crop at the time of cutting, and with the biomass yield, which is affected by the weather, soil, and crop growing conditions.

Perin et al. (2006) found substantial amounts of $\mathrm{N}$ derived from BNF present in the above ground parts of sunn hemp $(57.0 \%)$ grown isolated and $61.1 \%$ when intercropped with millet (50\% seeded with each crop). The sunn hemp + millet treatment grown before a maize crop resulted in higher grain yield than when sunn hemp alone was the preceding rotation. This effect was not observed when $\mathrm{N}$-fertilizer $\left(90 \mathrm{~kg} \mathrm{~N} \mathrm{ha}^{-1}\right)$ was added. Intercropping legume and cereals is a promising biological strategy to increase and keep $\mathrm{N}$ into the production system under tropical conditions (Perin et al., 2006). A large proportion of the $\mathrm{N}$ present in soybeans usually comes from BNF. Guimarães et al. (2008) found that $96 \%$ of the N present in above ground parts of soybeans were derived from $B N F$, values which are in agreement with those obtained by Perin et al. (2006) for sunn hemp. However, in the present study, only about $27 \%$ of the $\mathrm{N}$ present in the soybean residues were from BNF (Table 5), probably because of poor specific population of fixing bac-
Table 6 - Percentage of infection of natural arbuscular mycorrhizal fungus (AMF) in roots of rotational crops.

\begin{tabular}{lc}
\hline Rotational crops & Natural infection of AMF \\
\hline & $\%$ \\
Control & - \\
\hline Mung bean cv. M146 & $51 \mathrm{~b}$ \\
\hline Peanut cv. IAC-Caiapó & $74 \mathrm{a}$ \\
\hline Peanut cv. Tatu & $57 \mathrm{~b}$ \\
Soybean cv. IAC-17 & $56 \mathrm{~b}$ \\
Sunflower cv. IAC-Uruguai & $73 \mathrm{a}$ \\
Sunn hemp cv. IAC 2 & $49 \mathrm{c}$ \\
Velvet bean & $65 \mathrm{a}$ \\
\hline${ }^{1}$ C.V. (\%) & 15.9 \\
\hline
\end{tabular}

Means followed by the same letter in each column are not different (Scott-Knott, $p=0.05)$. ${ }^{1}$ Coefficient of variation.

teria for soybeans in the experimental site, which have been grown with sugarcane for long time. No inoculation of soybean with Bradyrhizobium was done. The contribution of $\mathrm{BNF}$ for the peanut varieties was significantly different: it reached $70 \%$ of the $\mathrm{N}$ in the cv. IACCaiapó but only $37.7 \%$ in the cv. Tatu (Table 5). Usually the natural population of rhyzobia is high enough to guarantee root colonization for peanuts but probably the bacteria population in the soil of the experimental site was not efficient for peanuts cv. Tatu.

The rate of natural colonization with AMF was relatively high in all crops (Table 6). Peanut cv. IAC-Caiapo and sunflower cv. IAC-Uruguai, followed by velvet bean, had at least $64 \%$ of root infection with AMF. At the same time, sunflower produced the greatest amount of aboveground biomass, followed by C. juncea and velvet bean. Soybean had the highest grain yield (Table 3) and also presented a considerable percentage of root infection with AMF: $56 \%$ (Table 6). Besides the symbiotic association with rhizobia, roots of the legumes can be colonized by fungi of the family Endogonaceae that form ve- 
sicular-arbuscular (VA) endomycorrhizas, which help enhance the uptake of phosphorus and other nutrients (Azcón-G. de Aguilar et al., 1979).

Results of a nursery study on the effect of a short season pre-cropping with different mycotrophic herbaceous crops on growth of arbuscular mycorrhiza-dependent mandarin orange plants at an early stage after transplantation were presented by Panja and Chaudhuri (2004). Mandarin orange seedling plants $180 \mathrm{~d}$ after transplantation showed variation in shoot growth in response to single season pre-cropping with seven different crops-maize, Paspalum millet, soybean, onion, tomato, mustard, and ginger, and two non-cropped fallow treatments-non-weeded and weeded fallows. Net growth benefit to the orange plants due to the different pre-crops and the non-weeded fallow treatment over the weeded fallow treatment plants showed a highly positive correlation with mycorrhizal root mass of the orange plants as it varied with the pre-crop treatments. Increase in citrus growth varied between 0 and 50\% depending upon the mycorrhizal root mass of the pre-crops and weeds, AMF spore number, and infective inoculum density of the pre-cropped soils. These pre-crop variables individually and cumulatively contributed to the highly significant positive correlation between the AMF potential of the pre-cropped soils and growth of mandarin orange plants through their effect on mycorrhizal root mass development (i.e. extent of mycorrhization) of the mandarin orange plants. The choice of a pre-crop from the available options, grown even for a short season, can substantially alter the inherent AMF potential of soils to a significant influence on the performance of the mycorrhiza-dependent orange plant. The relationship between soil mycorrhizal potential left by a pre-crop and mycorrhizal benefit drawn by the succeeding AMF responsive plant can be of advantage for the exploitation of native AMF potential of soils for growth and nutri- tion management of crops in low nutrient, low inputoutput systems of production (Panja and Chaudhuri, 2004).

The colonization with AMF was positively correlated to sugarcane plant height, at the first cutting (Table 7) ( $p=0.0105$ and $R=0.52$ ) although there was no correlation of AMF with other variables such as green manure yield, or stalk and sugar yields. The fact that sunn hemp had a relatively poor AMF infection compared with the other rotational crops (Table 6) but did not negatively affect sugarcane yield is probably one of the reasons for the low correlation of AMF with stalk or sugar yield. When legumes with high BNF capacity are involved in the rotation, the $\mathrm{N}$ contribution is likely to be higher than that of AMF for grasses that take up large amounts of this nutrient. However, the contribution of mycorrhiza colonization in the rotational plants to the succeeding sugarcane crop cannot be ruled out but has to be better evaluated in other situations.

Sugarcane yield increased more than $30 \%$, in average, due to the rotational crops as compared with the control treatment; those benefits lasted up to the third harvest (Table 8). In the first cutting, sunflower was the rotational crop that induced the greater yield increase, followed by peanut cv. IAC-Caiapo, and soybean cv. IAC 17. Wutke and Alvarez (1968) observed that sunn hemp residues increased the sugarcane yield; in the first harvest after the green manure, the effect of the legume crop was better than that of chemical fertilization with nitrogen. Similar results were reported later by Mascarenhas et al. (1994), with a yield rise of 15.4 tons $\mathrm{ha}^{-1}$ of sugarcane stalks, which represented about $24 \%$ increase in relation to the control. Positive effects on stalk yields were also found by Caceres and Alcarde (1995) when sugarcane was grown after Crotalaria spectabilis, and by Mascarenhas et al. (1998), who cultivated sugarcane after sunn hemp and velvet bean.

Table 7 - Height of sugarcane plants grown after rotational crops planted before the first sugarcane cycle.

\begin{tabular}{lcccc}
\hline \multirow{2}{*}{ Rotational crops } & \multicolumn{2}{c}{ Sugarcane plant height } \\
\cline { 2 - 5 } & First cut & Second cut & Third cut & Average \\
\hline Control & 2.24 & 2.50 & 3.46 & 2.75 a \\
Mung bean cv. M146 & 1.98 & 2.44 & 3.60 & 2.67 a \\
Peanut cv. IAC-Caiapó & 2.32 & 2.50 & 3.68 & 2.83 a \\
Peanut cv. Tatu & 2.32 & 2.40 & 3.84 & 2.85 a \\
Soybean cv. IAC-17 & 2.08 & 2.58 & 3.76 & 2.80 a \\
Sunflower cv. IAC-Uruguai & 2.18 & 2.40 & 3.48 & 2.68 a \\
Sunn hemp cv. IAC 2 & 2.18 & 2.54 & 3.92 & 2.88 a \\
Velvet bean & 2.22 & 2.50 & 3.66 & 2.79 a \\
\hline Average & $2.19 \mathrm{C}$ & $2.48 \mathrm{~B}$ & $3.67 \mathrm{~A}$ & 0.08 \\
SEM & 0.04 & 0.02 & & \\
\hline
\end{tabular}

Means followed by the same small letter in each column and capital letter in the line are not different (Tukey-Kramer, $p>0.1)$. ${ }^{1}$ Standard error of the mean. SEM for comparison of rotational crops is 0.08 . 
Sunflower was the best rotational treatment, causing a yield increased of around $46 \%$ in the first harvest after the rotational crops (Table 8). Meanwhile, in the average of three cuttings, peanut showed an yield increase of around $22 \%$ whereas sunflower presented a $10 \%$ yield increase; these results are in agreement with those of Caceres and Alcarde (1995) and Mascarenhas et al. (1994).

The rotational crops also affected some soil attributes (Table 9). The organic matter content increased in the soil upper layer $(0-0.2 \mathrm{~m})$ with the cultivation of peanut cv. IAC-Tatu and velvet bean, and in the 0.2-0.4 $\mathrm{m}$ layer, with mung bean, sunflower IAC-Uruguai, and peanut cv. IAC-Tatu. The increase of soil exchangeable magnesium was also observed for peanut cv. IAC-Tatu and velvet bean, although the original $\mathrm{Mg}$ content was already high, according to Raij et al. (1997). Balkcom et al. (2007) observed that peanut residue did not contribute with significant amounts of $\mathrm{N}$ to a rye (Secale cereale L.) cover crop grown as part of a conservation system, but retaining peanut residue on the soil surface could protect the soil from erosion early in the fall and winter before a rye cover crop grows sufficiently to protect the typically degraded southeastern USA soils.

Sakai et al. (2007) worked with velvet bean and also reported soil fertility improvement, with the decrease of potential acidity, increase in $\mathrm{Ca}$ and $\mathrm{Mg}$ availability, and increase in base saturation (V\%). Increases in $\mathrm{Mg}$ concentration were also found by Ambrosano et al. (2005) who worked with sunn hemp as green manure. The presence of organic acids in decomposing plant residues can help Mg movement in the soil (Franchini, 2001). Crops with high C:N ratio may release $\mathrm{N}$ more slowly and cause an increase in $\mathrm{N}$ uptake by succeeding crop

Table 8 - Yield of millable stems of sugarcane grown after rotational crops planted before the first sugarcane cycle.

\begin{tabular}{lcccc}
\hline \multirow{2}{*}{ Rotational crops } & \multicolumn{3}{c}{ Stem yield } \\
\cline { 2 - 5 } & First cut & Second cut & Third cut & Average \\
\hline Control & $47.6 \mathrm{Bc}$ & $111.2 \mathrm{Aa}$ & $50.7 \mathrm{Ba}$ & 69.8 \\
Mung bean cv. M146 & $61.6 \mathrm{Bb}$ & $131.9 \mathrm{Aa}$ & $54.7 \mathrm{Ba}$ & 82.7 \\
Peanut cv. IAC-Caiapó & $67.6 \mathrm{Ba}$ & $130.6 \mathrm{Aa}$ & $58.0 \mathrm{Ba}$ & 85.4 \\
Peanut cv. Tatu & $60.6 \mathrm{Bb}$ & $114.9 \mathrm{Aa}$ & $66.8 \mathrm{Ba}$ & 80.8 \\
Soybean cv. IAC-17 & $67.5 \mathrm{Ba}$ & $124.9 \mathrm{Aa}$ & $56.7 \mathrm{Ca}$ & 83.1 \\
Sunflower cv. IAC-Uruguai & $69.5 \mathrm{Ba}$ & $105.2 \mathrm{Aa}$ & $55.3 \mathrm{Ca}$ & 76.7 \\
Sunn hemp cv. IAC 2 & $65.9 \mathrm{Bab}$ & $125.8 \mathrm{Aa}$ & $51.1 \mathrm{Ca}$ & 80.9 \\
Velvet bean & $61.3 \mathrm{Bb}$ & $116.3 \mathrm{Aa}$ & $61.2 \mathrm{Ba}$ & 79.6 \\
\hline Average & 62.7 & 120.1 & 56.8 & 1.65 \\
SEM ${ }^{1}$ & 0.85 & 3.80 & & \\
\hline
\end{tabular}

Means followed by the same small-case letter in the columns and capital letter in the lines are not different (Tukey-Kramer, $p>0.1)$.

${ }^{1}$ Standard error of the mean. SEM for comparison of rotational crops is 4.22 .

Table 9 - Organic matter and exchangeable magnesium in soil sampled after rotational crops.

\begin{tabular}{|c|c|c|c|c|c|c|}
\hline \multirow{2}{*}{ Rotational crops } & \multicolumn{3}{|c|}{ Organic matter } & \multicolumn{3}{|c|}{$\mathrm{Mg}$} \\
\hline & $0-0.2 \mathrm{~m}$ & $0.2-0.4 \mathrm{~m}$ & Average & $0-0.2 \mathrm{~m}$ & $0.2-0.4 \mathrm{~m}$ & Average \\
\hline & \multicolumn{3}{|c|}{$\mathrm{g} \mathrm{kg}^{-1}$} & \multicolumn{3}{|c|}{$\mathrm{mmol}_{\mathrm{c}} \mathrm{dm}^{-3}$} \\
\hline Control & $20 \mathrm{Ab}$ & $19 \mathrm{Ab}$ & 19 & 21 & 19 & $20 \mathrm{~b}$ \\
\hline Mung bean cv. M146 & $19 \mathrm{Ab}$ & $20 \mathrm{Aa}$ & 20 & 19 & 18 & $19 \mathrm{~b}$ \\
\hline Peanut cv. IAC-Caiapó & $21 \mathrm{Ab}$ & $19 \mathrm{Bb}$ & 20 & 24 & 15 & $20 \mathrm{~b}$ \\
\hline Peanut cv. Tatu & $23 \mathrm{Aa}$ & $21 \mathrm{Aa}$ & 22 & 29 & 23 & $26 \mathrm{a}$ \\
\hline Soybean cv. IAC-17 & $19 \mathrm{Ab}$ & $17 \mathrm{Bb}$ & 18 & 20 & 17 & $18 \mathrm{~b}$ \\
\hline Sunflower cv. IAC-Uruguai & $20 \mathrm{Ab}$ & $20 \mathrm{Aa}$ & 20 & 20 & 19 & $19 \mathrm{~b}$ \\
\hline Sunn hemp cv. IAC 2 & $19 \mathrm{Ab}$ & $18 \mathrm{Ab}$ & 18 & 19 & 17 & $18 \mathrm{~b}$ \\
\hline Velvet bean & $23 \mathrm{Aa}$ & $18 \mathrm{Bb}$ & 21 & 28 & 18 & $23 \mathrm{a}$ \\
\hline Average & 21 & 19 & 20 & $22 \mathrm{~A}$ & $18 \mathrm{~B}$ & 20 \\
\hline${ }^{1}$ C.V. (\%) & 8.1 & 8.1 & & 18.4 & 22.6 & \\
\hline
\end{tabular}

Means followed by the same small-case letter in the columns and capital letter in the line are not different (Tukey-Kramer, $p>0.1)$. ${ }^{1}$ Coefficient of variation. 
with long cycles such as sugarcane under tropical conditions.

The changes in soil properties were relatively small as should be expected with only one rotation (Table 9). The rotational crops can contribute with organic residues, but, in general, the amounts of organic $\mathrm{C}$ added to the soil are usually not enough to cause significant changes in soil organic matter in the short term. In addition, rotational plants that were grown before sugarcane could recycle nutrients that would otherwise be leached, contribute with $\mathrm{N}$ derived from BNF and keep some elements in plant available forms, which could be transformed into more recalcitrant forms if the soil lie fallow for some time. Despite those known benefits of keeping the soil covered with live vegetation, some of the results reported in Table 9 could also be the effect of natural soil variability or a statistical artefact.

The sugar content of sugarcane stalks is important because the raw material remuneration takes into account this parameter. Some crops that preceded sugarcane had a high effect on sugar yield (Table 10); this was observed mainly in the first harvest in areas where sunflower, peanuts and C. juncea were previously cultivated (Table 10). The 3-year average data showed a sugar yield increase, in the best treatment, of $3 \mathrm{t} \mathrm{ha}^{-1}$ in relation to the control. These results were already observed by Mascarenhas et al. (1994) and Caceres and Alcarde (1995) who found an average increase of 2.98 ton $^{-1}$ ha due to green manure crops grown before sugarcane.

Studying crop rotation with legume plants in comparison with a control with and without a mineral $\mathrm{N}$ addition, Mascarenhas et al. (1994) observed that, after a crop rotation, the sugarcane yield was higher after $C$. juncea and velvet bean, with 3.0 and 3.2 stalk tons $\mathrm{ha}^{-1}$ increase, respectively. The treatments with an addition of $\mathrm{N}$ fertilizer but no-rotation with green manure resulted in only 1.1 tons ha ${ }^{-1}$ of a sugar yield increase, in the average of three years, suggesting that the beneficial influence of leguminous plants is not restricted to the $\mathrm{N}$ left by the leguminous plants after harvest.

Framers must combine the resources of land, labor, management, and capital in order to derive the most profit. Since resources are usually scarce, maximizing returns on each one is important. Crop rotations provide income diversification. If profitability of one crop is reduced because of price variation or some unpredicted reason, income is not as likely to be adversely affected as if the whole farm was planted to this crop, provided that a profit potential exists for each crop in a rotation. This is especially important to the farmer with limited capital.

Some of the general purposes of rotations are to improve or maintain soil fertility, reduce the erosion, reduce the build-up of pests and diseases, best distribute the work load, reduce the risk of weather damage, reduce the reliance on agricultural chemicals, and increase the net profits. Crop rotations have fallen somewhat into disfavor because they require additional planning and management skills, increasing the complexity of farming operations.

Crop rotation can positively affect yield and increase profit (Table 11). Except for peanuts, all other rotational crops contributed to raise the net income. This was true both for the green manures (crotalaria juncea and velvet bean), as for the grain crops (soybean, sunflower and mung bean). Peanuts caused an increase in the sugarcane stalk yields relative to the control, especially in the first harvest (Table 8), but the high cost of production of this grain somewhat cancelled out the benefit of this rotation. However, in many sugarcane regions in São Paulo State peanuts are extensively grown in rotation with sugarcane, probably because in those sites yields are higher and the cost of production, lower. Mung beans are a niche crop. Although it provided a relatively high net

Table 10 - Sugar yields of three consecutive cuttings of sugarcane grown after rotational crops.

\begin{tabular}{|c|c|c|c|c|c|}
\hline \multirow{2}{*}{ Rotational crops } & \multicolumn{5}{|c|}{ Sugar yield } \\
\hline & First cut & Second cut & Third cut & Average & $\mathrm{SEM}^{2}$ \\
\hline & - & 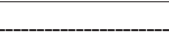 & $\mathrm{PH}^{1} \ldots$ & - & $\ldots$ \\
\hline Control & $6.9 \mathrm{Bb}$ & $18.1 \mathrm{Aa}$ & $7.5 \mathrm{Ba}$ & 10.3 & 1.4 \\
\hline Mung bean cv. M146 & $9.3 \mathrm{Ba}$ & $19.6 \mathrm{Aa}$ & $8.3 \mathrm{Ba}$ & 12.4 & 1.7 \\
\hline Peanut cv. IAC-Caiapó & $9.9 \mathrm{Ba}$ & $21.2 \mathrm{Aa}$ & $8.9 \mathrm{Ba}$ & 13.3 & 1.6 \\
\hline Peanut cv. Tatu & 8.8 Cab & $18.5 \mathrm{Aa}$ & $10.5 \mathrm{Ba}$ & 12.6 & 1.3 \\
\hline Soybean cv. IAC-17 & $10.0 \mathrm{Ba}$ & $17.7 \mathrm{Aa}$ & $8.8 \mathrm{Ba}$ & 12.2 & 1.3 \\
\hline Sunflower cv. IAC-Uruguai & $10.3 \mathrm{Ba}$ & $15.5 \mathrm{Aa}$ & $8.1 \mathrm{Ca}$ & 11.3 & 1.0 \\
\hline Sunn hemp cv. IAC 2 & $9.3 \mathrm{Ba}$ & $19.2 \mathrm{Aa}$ & $7.5 \mathrm{Ca}$ & 12.0 & 1.5 \\
\hline Velvet bean & $9.2 \mathrm{Ba}$ & $18.5 \mathrm{Aa}$ & $9.5 \mathrm{Ba}$ & 12.4 & 1.3 \\
\hline Average & 9.2 & 18.6 & 8.6 & & \\
\hline $\mathrm{SEM}^{2}$ & 0.2 & 0.6 & 0.3 & & \\
\hline
\end{tabular}

Means followed by the same small-case letter in the columns and capital letter in the lines are not different (Tukey-Kramer, $p>0.1$ ). ${ }^{1} \mathrm{TPH}=$ ton of pol per hectare. ${ }^{2}$ Standard error of the mean. 
Table 11 - Economic balance ${ }^{1}$ of sugarcane production including revenues and costs of crop rotation.

\begin{tabular}{lcrr}
\hline Rotational crop & Gross revenue $^{1}$ & Cost of production & Net income \\
\hline Control & 3,710 & 3,111 & $599 \mathrm{~b}$ \\
Mung bean cv. M146 & 6,131 & 5,118 & 1,012 a \\
Peanut cv. IAC-Caiapó & 4,784 & 4,591 & $193 \mathrm{~b}$ \\
Peanut cv. Tatu & 4,606 & 4,401 & $205 \mathrm{~b}$ \\
Soybean cv. IAC-17 & 4,961 & 3,624 & 1,337 a \\
Sunflower cv. IAC-Uruguai & 4,431 & 3,584 & 847 a \\
Sunn hemp cv. IAC 2 & 4,263 & 3,195 & 1,068 a \\
Velvet bean & 4,193 & 3,212 & $981 \mathrm{a}$ \\
\hline${ }^{2}$ C.V. (\%) & - & - & 24.1 \\
\hline
\end{tabular}

Means followed by the same letter in the column are not different (Scott-Knott, $p>0.05) .{ }^{1}$ Gross revenue includes sales of the three harvests of sugarcane plus grains of rotational crops. Cost of production includes land and crop management, chemicals, feedstock, and harvesting costs of all sugarcane and rotational crops, but excludes land rental. The rate index used to convert from Brazilian Real to U.S. dollar was $0.55 .{ }^{2}$ Coefficient of variation.

return in the present study (Table 11), the risks may be high due to the market restrictions and price fluctuations.

\section{Acknowledgements}

To Rogério Haruo Sakai from IAC/SAA and Ana Clarissa Alves Negrini from ESALQ/USP; to the technical research support of Ângela Maria C. da Silva, Gilberto Farias, Benedito Mota, Isac Serafim, and Maria Aparecida C. de Godoy; and to trainees Lais Ferraz de Camargo and Fernando Augusto Tassani Brefere. To FAPESP and CNPq for the grants.

\section{References}

Albuquerque, G.A.C.; Araújo Filho, J.T.; Marinho, M.L. 1980. Green manure and its economic importance. Boletim IAA/ PLANALSUCAR 1: 1-10. (in Portuguese).

Ambrosano, E.J.; Trivelin, P.C.O.; Cantarella, H.; Ambrosano, G.M.B.; Schammass, E.A.; Guirado, N.; Rossi, F.; Mendes, P.C.D. Muraoka, T. 2005. Utilization of nitrogen from green manure and mineral fertilizer by sugarcane. Scientia Agricola 62: 534-542.

Akaike, H. 1974. A new look at the statistical model identification. IEEE Transaction on Automatic Control, AC-19: 716-723.

Azcón, R.; Rubro, R.; Barea, J.M. 1991. Selective interactions between different species of mycorrhizal fungi and Rhizobium meliloti strains and theirs effects on growth, N2 fixation $\left({ }^{15} \mathrm{~N}\right)$ and nutrition of Medicago sativa L. New Phytologist 117: 399404.

Azcón-G. de Aguilar, C.; Azcón, R.; Barea, J.M. 1979. Endomycorrhizal fungi and Rhizobium as biological fertilisers for Medicago sativa in normal cultivation. Nature 279: 325-327.

Balkcom, K.; Wood, C.W.; Adams, J.F.; Meso, B. 2007. Suitability of peanut residue as a nitrogen source for a rye cover crop. Scientia Agricola 64: 181-186.

Bataglia, O.C.; Furlani, A.M.C.; Teixeira; J.P.F.; Furlani, P.R.; Gallo, J.R. 1983. Methods for Chemical Analysis of Plants. Instituto Agronômico, Campinas, SP, Brazil. (in Portuguese).

Caceres, N.T.; Alcarde, J.C. 1995. Green manuring with leguminous in rotation with sugar cane (Saccharum ssp). STAB 13: 16-20. (in Portuguese).
Franchini, J. C.; Meda, A. R.; Cassiolato, M. E.; Miyazawa, M.; Pavan, M.A. 2001. Plant residue extracts potential for lime mobility in the soil using a biological method. Scientia Agricola 58: 357-360.

Giovanetti, M.; Mosse, B. 1980. An evaluction of techniques for measuring vesicular arbuscular mycorrhizal spores. New Phytologist 84: 489-500.

Guimarães, A.P.; Morais, R.F.; Urquiaga, S.; Boddey, R.M.; Alves, B.J.R. 2008. Bradyrhizobium strain and the ${ }^{15} \mathrm{~N}$ natural abundance quantification of biological $\mathrm{N}_{2}$ fixation in soybean. Scientia Agricola 65: 516-524.

Littel, R.C.; Milliken, G.A.; Stroup, W.W.; Wolfinger, R.D. 1996. SAS System for Mixed Models. SAS Institute, Cary, NC, USA.

Mascarenhas, H.A.A.; Tanaka, R.T.; Costa, A.A.; Rosa, F.V.; Costa, V.F. 1994. Residual Effects of Legumes on the Physical and Economic Yield of Sugarcane, Instituto Agronômico, Campinas, SP, Brazil. (in Portuguese).

Mascarenhas, H.A.A.; Nogueira, S.S.S.; Tanaka, R.T.; Martins, Q.A.C.; Carmello, Q.A.C. 1998. Effect of productivity of crop rotation and summer and sunn henp in the winter. Scientia Agricola 55: 534-537 (in Portuguese, with abstract in English).

Miyasaka, S.; Okamoto, H. 1993. Organic matter. In: Going green on fertilization. Instituto Agronômico, Campinas, SP, Brazil. (in Portuguese).

Miyasaka, S. 1984. Historical study of green manure, legumes viable and their characteristics. In: Green manuring in Brazil. Fundação Cargill, Campinas, SP, Brazil. (in Portuguese).

Panja, B.N.; Chaudhuri S. 2004. Exploitation of soil arbuscular mycorrhizal potential for AM-dependent mandarin orange plants by pre-cropping with mycotrophic crops. Applied Soil Ecology 26: 249-255.

Perin, A.; Santos, R.H.S.; Urquiaga, S.; Guerra, J.G.M.; Cecon, P.R. 2006. Sunnhemp and millet as green manure for tropical maize production. Scientia Agricola 63: 453-459.

Philips, J.M.; Hayman, D.S. 1970. Improved procedures for cleaning roots and staining parasitic and vesicular arbuscular mycorrhizal fungi for rapid assessment of infection. Transactions of the British Mycological Society 55: 158-162.

Porto, W.S.; Carvalho, C.G.P.; Pinto, R.J.B.; Oliveira, M.F.; Oliveira, A.C.B. 2008. Evaluation of sunflower cultivars for central Brazil. Scientia Agricola 65: 139-144.

Raij, B. van; Cantarella, H.; Quaggio, J.A.; Furlani, A.M.C. 1997. Lime and Fertilizer Recommendations for Sao Paulo State. Instituto Agronômico, Campinas, SP, Brazil. (in Portuguese). 
Raij, B. van; Andrade, J.C.; Cantarella, H.; Quaggio, J.A. 2001. Chemical Analysis for Evaluation of the Fertility of Tropical Soils. Instituto Agronômico, Campinas, SP, Brazil. (in Portuguese).

Sakai, R.H.; Ambrosano, E.J.; Guirado, N.; Rossi, F.; Mendes, P.C.D.; Cantarella, H.; Arevalo, R.A.; Ambrosano, G.M.B. 2007. Agronomic evaluation of four species of mucuna used as green manure in agroecological systems. Revista Brasileira de Agroecologia 2: 910-913. (in Portuguese, with abstract in English).

SAS Institute. SAS/STAT Software 2004: Changes and Enhancements Through Release 8.2. SAS Institute, Cary, NC, USA.

Shearer, W.B.; Kohl, D.H. 1986. $\mathrm{N}_{2}$-fixation in field settings: estimations based on natural ${ }^{15} \mathrm{~N}$ abundance. Australian Journal of Plant Physiology 13: 699-756.
Silveira, P.M.; Braz, A.J.B.P.; Kliemann, H.J.; Zimmermann, F.J.P. 2005. Accumulation of nutrients in the leaves of Guandu and Estilosantes. Pesquisa Agropecuária Tropical 35: 133-138. (in Portuguese, with abstract in English).

Tanimoto, T. 1964. The press method of cane analysis. Hawaiian Planter's Record 57: 133-150.

Trivelin, P.C.O.; Salati, E.; Matsui, E. 1973. Prepare samples for ${ }^{15} \mathrm{~N}$ analysis by mass spectrometry. USP/CENA, Piracicaba, SP, Brazil. (in Portuguese).

Wutke, A.C.P.; Alvarez, R. 1968. Restoration of soil for the cultivation of sugar cane.Bragantia 27: 201-217. (in Portuguese, with abstract in English).

Received December 18, 2009

Accepted May 25, 2010 